\title{
W JAKI SPOSÓB PERYFERIE ROZMAWIAJĄ MIĘDZY SOBĄ ALBO TEORIA POSTKOLONIALNA POZBAWIONA „CENTRUM"1
}

\author{
TAMARA GUNDOROVA ${ }^{2}$ \\ (Ukraińska Akademia Nauk w Kijowie)
}

\begin{abstract}
Słowa kluczowe: latynoamerykańska teoria postkolonialna, transnowoczesność, dekolonizacja, postkolonialne peryferia, europejska prowincja, eurocentryzm, J. Herder, E. Dussel
\end{abstract}

Keywords: Latin American postcolonial theory, transmodernity, decolonization, postcolonial periphery, European province, eurocentrism, J. Herder, E. Dussel

\begin{abstract}
Abstrakt: Tamara Gundorova, W JAKI SPOSÓB PERYFERIE ROZMAWIAJĄ MIĘDZY SOBĄ ALBO TEORIA POSTKOLONIALNA POZBAWIONA „CENTRUM". „PORÓWNANIA” 15, 2014, T. XV, s. 33-44. ISSN 1733-165X. W artykule poddaje się analizie alternatywne koncepcje postmodernizmu opracowane przez filozofów latynoamerykańskich - transnowoczesności Enrique Dussela i dekolonizacji Waltera Mignolo oraz Rolando Vázqueza, które zostały oparte na krytyce europocentryzmu. Kolejnym aspektem tekstu jest analiza kolonialnego charakteru kulturologicznej koncepcji Johanna Herdera, w której Ukraina została skonstruowana jako europejski „Inny”. W artykule stwierdza się konieczność włączenia Ukrainy do dialogu alternatywnych praktyk postkolonialnych, które rozpościerają się horyzontalnie, na peryferii, od Ameryki Łacińskiej do Europy Wschodniej.
\end{abstract}

Abstract: Tamara Gundorova, HOW PERIPHERIES TALK TO EACH OTHER, OR THE THEORY OF POSTCOLONIALISM WITHOUT A “CENTRE". "PORÓWNANIA" 15, 2014, Vol. XV, p. 33-44. ISSN 1733-165X. The alternative conceptions of postmodernism developing by LatinAmerican philosophers - transmodernity by Enrique Dussel and decolonization by Walter Mignolo

${ }^{1}$ Artykuł powstał w ramach projektu naukowego NPRH Nr 12H 12004681 „Posttotalitarny syndrom pokoleniowy $\mathrm{w}$ literaturach słowiańskich Europy Środkowej, Wschodniej i PołudniowoWschodniej w świetle studiów postkolonialnych". Zaprezentowany został w ramach konferencji naukowej "Języki postkolonialności" zorganizowanej w ramach projektu NPRH 12H 110018 80, odbywającej się w dniach 2-3.06.2014 w Poznaniu.

2 Correspondence Address: hundorova@gmail.com 
and Rolando Vázquez who criticize eurocentrism are analyzed in the arcticle. Another point raised in the article is the analysis of a colonial character of the cultural utopian view of Johann Herder who constructed Ukraine as an European Other. The article shows the necessity of the inclusion of Ukraine into the dialogue of alternative postcolonial practices spread horizontally, on peripheries, from Latin America to Eastern Europe.

Natura oraz tzw. użyteczność studiów postkolonialnych już pod koniec XX w. stały się przedmiotem szerokiej debaty $w$ kołach akademickich. Uległa ona wyraźnemu zaostrzeniu po 11 września 2001 r., kiedy krytyka orientalizmu uzyskała nową radykalną treść, a Zachód ponownie zaczął być przedstawiany w opozycji do islamskiego Wschodu. Krytyka pobrzmiewa również w kręgu samych badaczy postkolonializmu. Podczas dyskusji przeprowadzonej w 2006 r. na Uniwersytecie Michigan mówiono o „potencjalnym wyczerpaniu paradygmatu postkolonialnego". Pod znakiem zapytania postawiono zresztą samo istnienie teorii postkolonialnej. The End of Postcolonial Theory? - pytała, podsumowując te obrady z perspektywy roku, redaktor PMLA (Publications of the Modern Language Association of America) Patricia Yaeger ${ }^{3}$.

W okrągłym stole wzięli udział czołowi przedstawiciele studiów postkolonialnych: Sunil Agnani, Fernando Coronil, Mamadou Diouf, Gaurav Desai, Simon Gikandi, Susie Tharu i Jennifer Wenzel. W centrum ich zainteresowania znalazła się kwestia "statusu studiów postkolonialnych w bieżącej sytuacji geopolitycznej”. Podczas dyskusji wyartykułowano trzy istotne idee. Po pierwsze, konieczność rozszerzenia ram epistemologicznych samego postkolonializmu, kiedy aktualności nabrało nie tylko zagadnienie oporu antykolonialnego, lecz również potrzeba ustalenia odmienności między różnymi imperializmami - np. Nigerią czasów kolonializmu oraz Nigerią pod rządami generalnego gubernatora lorda Fredericka Lugarda. Po drugie, unaoczniła się dyfuzja samej teorii postkolonialnej, w wyniku rozszerzenia jej ram historycznych i geograficznych, od czasu, gdy - mówiąc w pewnym uproszczeniu - do sfery postkolonializmu zaliczane są średniowieczne formacje proto-nowoczesne, a do obydwu Ameryk i Azji, kojarzonymi ze studiami postkolonialnymi najczęściej, dołączyła również Afryka. W tymże kontekście wygłoszono tezę o dryfowaniu studiów postkolonialnych ku postradzieckiej wschodniej Europie, która: „Adaptuje ankietowe rubryki dla przewidywanego (emigranckiego?) Trzeciego świata, w tym celu, by zinterpretować na nowo powstały Drugi świat"4.

${ }^{3}$ Editor's Column: The End of PostcolonialTheory? A Roundtable with Sunil Agnani, Fernando Coronil, Gaurav Desai, Mamadou Diouf, Simon Gikandi, Susie Tharu, and Jennifer Wenzel. „PMLA” 2007, Vol. 122, nr 3, s. 633-651.

${ }^{4}$ Ibidem, s. 648 . 
We wstępie do specjalnego wydania czasopisma "Journal of Postcolonial Writing" (2008), pod tytułem Nowe kierunki w studiach postkolonialnych (New Directions in Postcolonial Studies) Alec Hargreaves i David Murphy dokonali przeglądu stanu badań. Autorzy zwracają uwagę, że - z jednej strony - obserwujemy dziś próby przemodelowania badań postkolonialnych i nakreślenia ich regionalnych odmian, np. francuskojęzycznej ${ }^{5}$, z drugiej zaś - możemy spotkać się z poglądami o swoistym „końcu teorii postkolonialnej”. Widać jednak wyraźnie, że ten kierunek intelektualny wykracza poza ramy nurtów literatury angielskiej, z której się wywodzi ${ }^{6}$.

Warto zwrócić uwagę na poszukiwania typów postkolonializmu alternatywnych wobec wariantu anglosaskiego. Wyróżniamy dziś odmianę latynoamerykańską, portugalską i inne. Specyfika tych ostatnich tłumaczona jest ich podwójną treścią: są one bowiem związane $\mathrm{z}$ dyskursem postkolonialnym wytworzonym przez anglosaską północ, a jednocześnie zakorzenione w dyskursie oporu, wyrastającym na południu7. Mówiąc ogólnie, w aktywnych dyskusjach dotyczących postkolonializmu odzwierciedlają się zmiany współczesnej sytuacji geopolitycznej, kiedy obiektem analizy stają się zjawiska dotyczące innych imperiów, migracji, modernizacji, rozwoju kultury masowej, studiów genderowych, teorii traumy. Taki kontekst czyni zasadnym mówienie o innych, także zdecentrowanych postkolonializmach.

\section{„ZDECENTROWANE” TEORIE POSTKOLONIALIZMU}

\section{Teoria transnowoczesności}

Współcześnie coraz wyraźniejszą staje się tendencja do nadawania nowego sensu całej teorii postkolonialnej, prezentowanej z punktu widzenia Innego, w tym nie-Europejczyka. To nowe krytyczne spojrzenie, od strony tzw. peryferyjnej kultury postkolonialnej - stale kojarzonej z krajami Azji, Afryki i Ameryki Łacińskiej - pomaga nie tylko $\mathrm{w}$ wyrażeniu punktu widzenia przedstawiciela subaltern, lecz niesie ze sobą także projekt odmiennej koncepcji całej kultury europejskiej.

W tym kontekście istotne jest przeanalizowanie alternatywnych wizji postkolonializmu, wypracowanych przez zachodnich filozofów i krytyków nie-zachodnich. Wśród nich szczególnie interesującymi są koncepcja transnowoczesności (transmodernity) oraz teoria dekolonizacji. Obie powstały na gruncie kolonializmu,

${ }^{5}$ T. Bonnie, Francophone postcolonial studies: past, present and future. „Postcolonial Studies” 2010, Vol. 13, nr 2, s. 223-227.

${ }^{6}$ A. G. Hargreaves, D. Murphy, Introduction: New Directions in Postcolonial Studies. „Journal of Postcolonial Writing" 2008, Vol. 44, nr 3, s. 221-225.

7 A. M. Martins, Gender and the "postcolonial exotic". "The Journal of Commonwealth Literature" 2013, Vol. 48, nr 1, s. 153. 
odmiennego od jego wersji angloamerykańskiej w ujęciu Edwarda Saida. Twórcami teorii transnowoczesności i teorii dekolonizacji są krytycy pochodzenia latynoamerykańskiego. Koncepcję transnowoczesności rozwija znany filozof pochodzenia argentyńskiego Enrique Dussel. Podstawę jego teorii stanowi przedefiniowanie europocentryzmu i europejskiej idei nowoczesności. „Nowoczesność jest fenomenem nie Europy jako niezależnego systemu, lecz Europy jako centrum"8 - uważa filozof, podkreślając wagę „inkorporacji” przedkolumbijskiej Ameryki (Amerindie) $)^{9}$ dla ustanowienia europocentryzmu i roli „centralnego zarządzania" płynącego z Europy dla całokształtu koncepcji nowoczesności. A zatem, jego zdaniem, właśnie utworzenie peryferii na kontynencie latynoamerykańskim w wyniku wielkich odkryć geograficznych oraz późniejsze rozszerzenie tych peryferii umożliwiają Europie jej „scentrowanie”, przeobrażając ją w swego rodzaju „świadomość refleksywną" historii światowej. Do peryferii, które powiększają swój obszar w okresie nowoczesności, Dussel zalicza Amerindie, Brazylię, wybrzeże Afryki i Polskę - w wieku XVI; zjednoczoną Amerykę Łacińską, Amerykę Północną, Wyspy Karaibskie i Europę Wschodnią - w XVII w. oraz Imperium Osmańskie, Rosję, niektóre z państw indyjskich, subkontynent azjatycki oraz Afrykę kontynentalną - w pierwszej połowie wieku XIX10.

Ogółem, powstanie głębokiego podziału między tzw. zachodnią metropolitarną kulturą europocentryczną a postkolonialnymi kulturami peryferii, podobnie jak między wykształconą na sposób zachodni elitą i kulturą popularną większości mieszkańców, Dussel uważa za bezpośrednie następstwa europocentrycznej nowoczesności. Jego teoria transnowoczesności opiera się tymczasem na idei wykorzystania potencjału tzw. peryferii oraz tzw. kultury popularnej (ludowej). Ta ostatnia symbolizuje zewnętrzność wobec uniwersalnej kultury zachodniej. Zaprzeczając opozycji „cywilizacji uniwersalnej” i „kultury narodowej” - przedstawianej przez Paula Ricoeura z punktu widzenia esencjalizmu europocentrycznego, który ustanawiał hierarchiczny system odniesień - Dussel akcentuje szczególne znaczenie kultury rozumianej jako konstytutywna mityczno-wartościująca esencja narodu. Podkreśla on, że historia kulturowa Ameryki Łacińskiej, wraz z jej hybrydycznością i niestałością, odbierana jest często jako zjawisko marginalne w stosunku do kultury europejskiej. A przecież, konstatuje filozof, „kultura taka istnieje", a jej szczególnie produktywny komponent stanowi kultura popularna (ludowa).

Kultura latynoamerykańska, zgodnie z poglądem uczonego, mieści w sobie dojrzałe ślady inwazji imperialnej. Kultura „imperialna” wstępuje tu w szranki

8 È. Dûssel, Po tu storonu evropocentrizma: Mirosistema i predely modernosti. „Perekrëstki. Žurnal issledovanij vostočnoevropejskogo pograniččâ" 2008, nr 1, s. 151.

${ }_{9}^{9}$ Autorka w oryginale stosuje na określenie Ameryki przed Kolumbem za Dusselem nazwę "Amerindie" w Polsce mało znaną.

${ }^{10}$ Ibidem. 
$\mathrm{z}$ "peryferyjnymi” kulturami ludowymi, podlegającymi zazwyczaj marginalizacji, eksploatacji i wyniszczaniu - podobne procesy dotyczą również Ameryki Łacińskiej, Afryki, Azji i Europy Wschodniej ${ }^{11}$. W ten sposób kształtuje się asymetryczne pole kulturowe, w którym europejska i zachodnia kultura metropolitarna kojarzona jest z cywilizacją, zacierając kultury peryferyjne, a kultury postkolonialne rozpadają się na kulturę wykształconych elit, odcinających się od swych regionalnych korzeni, i ludową kulturę większości - zmuszonej do obrony swojej tradycji, często metodami fundamentalistycznymi.

Sedno filozofii wyzwolenia stworzonej przez Dussela polega na przyjęciu za punkt wyjścia kultury peryferyjnej przeciwstawionej kulturze imperialnej, a mówiąc ściślej: kultury ludowej, która zawiera w sobie „folklor, muzykę, potrawy, odzież, festiwale, pamięć o bohaterach, walkach wyzwoleńczych, organizacjach społecznych i politycznych"12. Charakterystyczne, że Dussel nie utożsamia ani „kultury masowej”, ani „kultury narodowej” z „kulturą popularną”, a rękojmię alternatywnej modernizacji (czy, w jego terminologii, transnowoczesności) wiąże z kulturą popularną grup etnicznych, artystów i ludzi marginesu.

W miejsce teorii postnowoczesności, która zdaniem argentyńskiego filozofa stanowi jedynie korekturę do nowoczesnej kultury zachodniej, Dussel proponuje pojęcie transnowoczesności. Jego zasadniczą oznaką jest z gruntu zewnętrzna pozycja, wykształcona poprzez odmienność jako taką, wypływającą „z innego miejsca, innej lokalności"13. Taka perspektywa z punktu widzenia peryferii jest globalna. Natomiast europejską perspektywę określa Dussel mianem prowincjonalnej. Nie chodzi o odnalezienie centrum lub jego zdegradowanie, podobnie jak nie o to, by „ulokalnić” Amerykę Łacińską, uważa argentyński filozof, lecz o to, by „spróbować usytuować wszystkie kultury, które dziś nieuchronnie konfrontują się ze sobą, na wszystkich poziomach życia społecznego - od komunikacji, oświaty i pracy naukowej do polityki ekspansji i walki kulturowej lub nawet militarnej14.

W istocie zagadnienie nie dotyczy „splotu konsensusów”, który byłby możliwy za sprawą częściowego zaakceptowania wartości zachodnich przez wszystkich członków społeczności światowej - łącznie z peryferiami. Mowa tu raczej o solidarności tych wszystkich, których nowoczesność zachodnia oddelegowała na peryferie. Transnowoczesność w ścisłym sensie tego słowa, w myśl koncepcji Dussela, zmienia radykalnie dotychczasową perspektywę - zewnętrzną $\mathrm{w}$ stosunku do nowoczesności europejskiej. Ów nowy punkt widzenia postrzega się jako wyzwa-

${ }^{11}$ E. Dussel, Transmodernity and Interculturality: An Interpretation from the Perspective of Philosophy of Liberation. „Transmodernity: Journal of Peripheral Cultural Production of the Luso-Hispanic World” 2012, Vol. 1, nr 3, s. 33.

${ }^{12}$ E. Dussel, ibidem, s. 36.

${ }^{13}$ Ibidem, s. 42.

${ }^{14}$ Ibidem, s. 37. 
nie rzucone tej ostatniej, ukierunkowane na poszukiwania odmienności, a więc na odpowiedź z innego miejsca, innej lokalności.

Kultury odmienne udzielają tej odpowiedzi z perspektywy ich własnych doświadczeń, odróżniających się od europejskich/północnoamerykańskich. Mówiąc ogólnie, kultura transnowoczesna: a) przyswaja pozytywne aspekty Nowoczesności, zwłaszcza wiedzę i doświadczenie wykształconych elit postkolonialnych; b) jest różnorodna i stanowi produkt autentycznego dialogu interkulturowego; c) uzmysławia istniejącą asymetrię („centrum” i „peryferie”), nie dążąc do jej przezwyciężenia. „Kultury postkolonialne wymagają efektywnej dekolonizacji, ale rozpocząć powinny one z dowartościowania samych siebie"15 - uważa Dussel, który na miejscu priorytetowym umieszcza afirmację, jako sposób na samopotwierdzenie.

A zatem transnowoczesność istnieje na bazie dialogu międzykulturowego, pojednując w sobie wszystkie aspekty, które znajdują się "poza” strukturami wartościowymi dla nowoczesnej kultury europejskiej/północnoamerykańskiej, takimi jak: rozum, postęp, klasyka. Przeciwnie - jest ona pozytywnie zakorzeniona w tradycji odmiennej od Nowoczesności. Mówimy tu wszakże nie o zunifikowanej i bezbarwnej jedności, lecz o różnorodności (dialogu) odmienności kulturowych wytwarzanych przez wspólnoty postkolonialne horyzontalnie - od peryferii do peryferii. Takie horyzontalne związki łączą ze sobą ruch ekologiczny i feministyczny, antyrasizm i antysowietyzm, obronę zwierząt i ruch wolontariacki. Jednocześnie owe komunikujące się ze sobą „odmienności” przystępują do dialogu właśnie jako ci, którzy zostali odrzuceni przez panujące "centrum”, ale w żadnym razie nie leży $\mathrm{w}$ ich intencji opanowanie lub obalenie takowego centrum. Rozwój kultury wiązać ma się raczej ze wzrostem oporu kulturowego - nie tylko wobec elit innych kultur, lecz także wobec europocentrycznych elit $\mathrm{w}$ tzw. peryferyjnych kulturach kolonialnych.

Rzecz jasna, taki transnowoczesny dialog międzykulturowy rozpatrywać można jako zwielokrotnioną utopię, ważne jednak, że w orbicie tej przebywają na równi wszelkie marginalne i peryferyjne praktyki kulturowe - narodowe, społeczne, klasowe, rasowe i genderowe. Na jednakowych prawach prowadzą tu dialog Trzeci i Drugi świat, postkolonialne kraje Afryki, Azji, Ameryki Łacińskiej oraz posttotalitarnej i postradzieckiej Europy Wschodniej.

\section{Teoria dekolonizacji}

Z teorią Dussela koresponduje teoria dekolonizacji Waltera Mignolo i Rolando Vázqueza. Dekolonizacja to jedna z gałęzi współczesnych studiów postkolonial-

${ }^{15}$ Ibidem, s. 44. 
nych, zapoczątkowana jeszcze $\mathrm{w}$ roku 1998 jako projekt uczonych i intelektualistów z Ameryki Północnej i basenu Morza Karaibskiego, a także pracujących w USA badaczy południowoamerykańskich. Mignolo i Vázquez pojmują dekolonialność jako zjawisko łączące $\mathrm{w}$ sobie trzy pojęcia - modernity, coloniality, decoloniality - w jednym słowie - modernity/(de)coloniality, stanowiącym oznaczenie dla tych pojęć w ramach jednego konceptu. Chodzi o jednoczesne i symultaniczne przebywanie $\mathrm{w}$ stanie nowoczesności i kolonialności oraz ich przezwyciężenie dekolonizację.

Koncept taki opisuje sytuację konfliktu: $\mathrm{z}$ jednej strony retoryka nowoczesności wraz z jej obietnicą ocalenia, z drugiej - logika kolonialności, zakładająca ukryte procesy przywłaszczania, eksploatacji i korupcji, które, poprzez działalność instytucji, korporacji i zindustrializowanych narodów-państw, wpływają destrukcyjnie na samą narrację o nowoczesności. Dekolonialność wypełnia przestrzeń między nowoczesnością i kolonialnością jako otwarta możliwość pogodzenia sprzeczności między nimi. Jednocześnie dekolonialność odwołuje się do globalno-lokalnych historii regionu południowoamerykańskiego, przeplatających się z imperialnymi dziejami euro-amerykańskiej nowoczesności oraz postnowoczesności ${ }^{16}$.

Projekt dekolonialny został zaprezentowany w sposób najwyraźniejszy poprzez manifest estetyki dekolonialnej. Podobnie jak i sam projekt dekolonizacji, estetyka dekolonialna zwraca się do „wyzwolenia odczuwania i wrażliwości” zniewolonych przez nowoczesność i najciemniejszą z jej stron - kolonialność17. W swojej istocie owa kolonialna estetyka jest interkulturową (w odróżnieniu od multikulturalizmu Ameryki Północnej), interepistemologiczną, interpolityczną, interestetyczną oraz interduchową. Należy zwrócić uwagę na rozszerzenie sfery działania dekolonizacji - w jej orbicie znajdują się i Chiny, i postsocjalistyczna Europa Wschodnia (Rumunia, Rosja). Ideolodzy dekolonializacji podkreślają przy tym, że wszelka krytyka zachodniego projektu nowoczesności odbywa się „z perspektywy globalnego Południa i byłej Europy Wschodniej"18.

Ideologia dekolonizacji ukierunkowana jest na odbudowę tożsamości zdyskredytowanych przez nowoczesność. Zdaniem jej teoretyków, wytworzyła ona hierarchie: rasową, seksualną, narodową, lingwistyczną, religijną i ekonomiczną. Zadaniem takiej estetyki jest danie wyrazu tożsamości transnarodowej i opowiedzenie na nowo ukrytych narracji kolonializmu. Charakterystyczna cecha takiej estetyki to apelowanie do pograniczności. Twórcy manifestu estetyki dekolonialnej głoszą, że są oni motorami nowego dekolonialnego transnowoczesnego myśle-

${ }^{16}$ W. Mignolo, R. Vázquez, Decolonial AestheSis Colonial Wounds Decolonial Healings, „Social Text.htm", http://socialtextjournal.org/periscope_article/decolonial-aesthesis-colonial-woundsdeco lonial-healings/ (data dostępu: 27.11.2014)

17 Decolonial Aesthetics (I), http://transnationaldecolonialinstitute.wordpress.com/decolonial-aes thetics/ (data dostępu: 27.11.2014).

18 Ibidem. 
nia: mieszkają na pograniczu, odczuwają na pograniczu, na pograniczu także działają.

Tym sposobem, począwszy od roku 2009, formułuje się specyficzna estetyka dekolonialna określana jako esteZa - dla odróżnienia od powstałej w świadomości zachodniej esteTyki. Esteza uznawana jest za ruch, który określa i artykułuje kulturowe oraz uczuciowe praktyki o charakterze wyzywającym i subwersywnym, wymierzone przeciw hegemonii nowoczesnej (kolonialnej) estetyki, która - sądzą teoretycy dekolonizacji - narzuca kulturom całego świata uniwersalne, opierające się na racjonalizmie, modele piękna. Tak pojmowana esteza stanowi unaocznienie niewidzialnego - tego, czego nie docenia nowoczesna estetyka, sama stanowiąca jedno z narzędzi kolonizacji. Dla estezy środkiem oporu jest prze-egzystowanie, które stwierdzić można na podstawie odczuwania, smaku, codziennych praktyk estetycznych i cielesnych. A zatem esteza oznacza przede wszystkim dekolonizację odczuwania i wrażliwości.

Popularna wśród twórców południowoamerykańskich teoria dekolonizacji zyskuje zwolenników i na wschodzie Europy. Rosyjska filozof i kulturolog Madina Tłostanowa, aktywna popularyzatorka estetyki dekolonialnej, konstatuje niedwuznacznie, że esteza dekolonialna to sfera uczuciowego postrzegania świata, a sama dekolonizacja stanowi teorię wyzwolenia wiedzy i bytu od ograniczeń estetyki zachodniej. Oponując przeciw zachodniej teorii postmodernizmu, wskazuje ona na możliwość uwzględnienia nowej optyki retorycznej: „zamiast hybrydyzować [Jacques'a] Lacana z indyjską historią kolonialną i podmiotowością i stwarzać bogate polisemantyczne pojęcia $\mathrm{w}$ duchu Homiego Bhabhy, można rozpoczynać dyskusję nie od Lacana, a, dla przykładu, od chicana-queer-feministki Glorii Anzaldúa lub od meksykańskich sapatystów, od kosmologii kaukaskiej lub sufizmu"19.

I choć słownik estezy dekolonialnej został już ułożony, wciąż brakuje mu konkretnej i analitycznej praktyki. Dla nas ważniejsza jest inna kwestia - krytyka dekolonialna rodzi się na peryferiach i: a) stanowić ma opozycję do zachodnich teorii nowoczesności i postnowoczesności; b) zakłada w sobie dialog interkulturowy, przypominający koncepcję transnowoczesności Dussela; c) przewiduje ruch od peryferii do peryferii (Karaiby, Azja Południowa, Europa Wschodnia); d) oznacza przeniesienie optyki z racjonalności na odczuwanie i wrażliwość; e) podobnie jak transnowoczesność, współdziała z praktykami świadomości pogranicznej.

Gwoli sprawiedliwości warto odnotować, że zarówno teoria trans-nowoczesności Dussela, jak i teoria dekolonizacji Mignolo i Vázqueza nie negują zdobyczy zachodniej nowoczesności jako takiej - są raczej ukierunkowane na jej skorygowanie. $W$ pewnym sensie można je również rozpatrywać jako lokalne teorie samego postmodernizmu.

${ }^{19}$ M. Tlostanova, Postkolonialalnaâ teoriâ, dekolonialnyj vybor i osvoboždenie êstezisa, http://e-nota bene.ru/ca/article_141.html (data dostępu: 10.12.2014). 


\section{UKRAINA I/JAKO EUROPEJSKA PROWINCJA}

Jak widać, obie zaproponowane przez latynoamerykańskich filozofów teorie włączają do swej orbity również posttotalitarną Europę Wschodnią. Czy mogą one znaleźć zastosowanie $\mathrm{w}$ takim przypadku jak Ukraina - a jeśli tak, to w jaki sposób? W pierwszej kolejności spróbujmy rozmieścić (usytuować) na mapie Europy ukraińską tożsamość.

Zgodnie z tradycją korzenie tożsamości europejskiej kojarzone są z dziedzictwem śródziemnomorskim - kulturą grecko-rzymską oraz chrześcijaństwem, renesansem, etyką protestancką (Max Weber). Sama idea europeizmu na osi GrecjaRzym-Europa została sformułowana i uzasadniona w ramach niemieckiego oświecenia i romantyzmu w końcu XVIII w. - w pracach Friedricha Schillera, Johanna Winckelmanna, Wilhelma Humboldta, Georga Hegla i Johanna Herdera. W istocie ugruntowywali oni przewodnią rolę Europy w dziejach świata. Mimo to, jak przekonują współcześni badacze historii antycznej, starożytne Grecja i Rzym nie posiadały żadnego wyobrażenia o wspólnej Europie, nie istniało także samo geograficzne pojęcie Europy, jako takiej. Funkcjonowało natomiast przeciwstawianie zachodnich prowincji Imperium Rzymskiego - łącznie z ziemiami północnoafrykańskimi, gdzie językiem komunikacji była łacina - i Wschodu: Grecji i części Azji (Anatolii), gdzie językiem komunikacji była greka.

Ogółem świat antyczny, zdaniem uczonych, był polikulturowy i wielojęzyczny. Nawet $\mathrm{w}$ wiekach średnich łacińska Europa tworzyła drugą, peryferyjną wobec świata muzułmańskiego, kulturę. Jak podkreślał wspominany już Dussel, Imperium Rzymskie nigdy nie stało się centrum dziejów kontynentu euro-afroazjatyckiego ${ }^{20}$. Rzeczona kultura grecko-rzymska nie była żadnym monolitem. Martin Heidegger analizował rolę odgrywaną przez Rzym (lub rzymską reinterpretację klasycznej greckiej filozofii, kultury i polityki) w kodyfikacji europejskiej tożsamości kulturowej21 i, odwołując się do najstarszych źródeł, rozwiał wyobrażenie o grecko-rzymskiej tradycji składającej się na jedną całość, która miała stworzyć podwaliny dla tożsamości europejskiej. Filozof podkreślał, że myśl i kultura starożytnej Grecji i Rzymu różniły się radykalnie: „pierwsza tworzyła kulturę zorientowaną na odmienność, druga - na zasadę tożsamości; pierwsza dochowywała wierności agonistycznej polis, druga (nawet na etapie republikańskim) - dedykowana była państwu imperialnemu ${ }^{22}$.

A jak przedstawiano świat słowiański w europejskiej koncepcji romantycznego okcydentalizmu? Jednym z przedstawicieli tego nurtu był wspomniany Johann

${ }^{20}$ E. Dussel, Europe, Modernity, and Eurocentrism. "Nepantla: Views from South” 2000, Vol. 1, nr 3, s. 466 .

${ }^{21}$ W. Spanos. Heidegger's Parmenides: Greek Modernity and Classical Legacy. „Journal of Modern Greek Studies" 2001, Vol. 9, s. 91.

22 W. Spanos, ibidem, s. 92. 
Herder (1744-1803). Jego zainteresowanie kulturami narodowymi i poezją ludową zrodziło się na tle negacji wzorców cudzoziemskich, szeroko wprowadzanych w Niemczech i całej Europie przez oświeceniową estetykę. W okresie podbojów imperialnych i kolonizacji, Herder już to utożsamiał się z europejskim centrum kulturowym, już to stawał po stronie ludów prowincjonalnych lub skolonizowanych - także słowiańskich - wyrażając sympatię w stosunku do patriarchalnej słowiańszczyzny i prognozując jej przyszłe odrodzenie. Podstawę dla tej teorii stanowiło przywiązanie do miejsca ojczystego, homogeniczność kultury zakorzenionej w ziemi, tradycji i języku, a także utożsamienie "naturalnego" (organicznego) państwa z ludnością, która ma własne oblicze narodowe oraz język. Ruch kolonialny, według wizji Herdera, doprowadza do hybrydyzacji narodów, zmieszania ras i osłabienia państwa, powoduje wreszcie degenerację samych kolonizatorów, nieprzystosowanych do obcego klimatu. Rozwój kultury zaś, zdaniem Herdera, następuje w sposób organiczny - poprzez zaszczepianie kultury, wzajemne przenikanie się kultur i ich zespalanie.

Idee Herdera wywarły znaczny wpływ na słowiański, w tym również ukraiński, romantyzm - także w zakresie docenienia odrębności etnonarodowościowej, choć z pola widzenia ukraińskich romantyków umknął fakt, że Herder miał na myśli odrodzenie nie Słowian, lecz „pogrążonej we śnie” Europy XVIII w. W znanym dzienniku z wędrówek w roku 1769 (Journal meiner Reise im Jahr 1769) zanotował on, że nową siłę - zdolną do przeprowadzenia duchowego odrodzenia Europy jako centrum światowej historii - dostrzega on nie na północy i zachodzie, lecz na wschodzie i południu. Na kartach swoich „politycznych fantazji przywianych przez morze" Herder zaakcentował szczególną rolę ludów, które w przyszłości nabiorą kultury, również i mieszkańców Ukrainy. „Ukraina stanie się nową Grecją; - snuł swoją wizję - Piękne niebo tego ludu, jego wesołe usposobienie, jego muzykalna natura, urodzajna ziemia etc. kiedyś się przebudzą"23.

Projekt taki stanowi w gruncie rzeczy kolonialną utopię cywilizacyjną. Mowa tu o przyszłym "cywilizowanym narodzie”, który ma się narodzić pośród "małych dzikich ludów, jakimi w przeszłości byli również Grecy". Ziemie zamieszkałe przez ów naród "[...] będą się ciągnąć aż do Morza Czarnego, a stamtąd dalej w świat. Węgry, część Polski i Rosji będą uczestniczyć w tej nowej kulturze"24.

Taka idealna kraina - Ukraina przypomina wynaleziony przez romantyków nowoczesny naród - Grecję. Jak zauważa m.in. William Spanos, Grecja nowoczesna w rzeczy samej nie była niczym innym jak „monumentalnym wyobrażeniem o Grecji klasycznej", wynalezionej przez działaczy Oświecenia, była więc tak naprawdę „zromanizowaną Grecją" 25 i w luźny sposób odnosiła się do realnej Grecji

\footnotetext{
${ }^{23}$ J. G. Herder, Dziennik mojej podróży z roku 1769. Przeł. T. Namowicz. Olsztyn 2002, s. 63.

${ }^{24}$ Herder, ibidem.

${ }^{25}$ W. Spanos, Heidegger's Parmenides... op. cit., s. 106.
} 
XVIII i XIX w. O takiej właśnie idealnej Grecji-Ukrainie przyszłości, mającej rozkwitnąć w miejsce "małych dzikich ludów”, jakimi byli niegdyś Grecy” mówi także Herder.

W istocie Herderowska refleksja odzwierciedlała formułowanie się ogólnoeuropejskiej historiografii i kulturozofii w czasach późnego Oświecenia, kiedy wiele uwagi poświęcano peryferyjnym pograniczom cywilizacji europejskiej. Podstawą tej cywilizacji, do której według Herdera dołączyć ma kiedyś świat słowiański, jest "duch kultury", a więc oświata. Duch ten winien być przyniesiony z zewnątrz. Wszak przyszłość nowych ucywilizowanych kultur dostrzegalna jest nie od wewnątrz, z punktu widzenia ich autonomicznego poczucia wartości własnej, lecz „jeśli spojrzeć na nie z Północy i Zachodu”, a więc z perspektywy już cywilizowanych krajów europejskich. Herder wytycza granice takiej Europy, wyliczając odwiedzone przez siebie kraje: „Płynąłem statkiem wzdłuż wybrzeży Kurlandii, Prus, Danii, Szwecji, Norwegii, Jutlandii, Holandii, Szkocji, Anglii, Niderlandów, aż do Francji"26. Można by zresztą uszczegóławiać poziom ucywilizowania każdego $\mathrm{z}$ wymienionych krajów, jednak $\mathrm{w}$ tym przypadku znamienna jest przede wszystkim perspektywa - z Północy i Zachodu, ukierunkowana na Wschód i Południe Europy. Uwagę przykuwa również i to, że Herder absolutnie niweluje historię i kulturę tych ludów, które jeszcze nie zaznały błogosławionego ducha cywilizacji. „To wszystko nas czeka i musi się kiedyś wydarzyć. Ale jak? Kiedy? Dzięki komu? Jakie zalażki kryje w sobie duch tamtejszych ludów, by wydać mitologię, poezję, $\dot{z} y w a$ kulturę27 [wyróżnienie moje - T. H.], - taksuje twórczą moc ludów słowiańskich Herder - przekonany najwyraźniej, że żadnej mitologii, poezji i kultury one jeszcze nie posiadają.

Tę opozycję rozwinie później Hegel i sformułuje jednoznaczne pojęcie Europy jako Zachodu. „[...] jak Europa jest w ogóle środkiem i kresem Starego Świata i jest bezwiednie Zachodem, tak Azja - bezwzględnie Wschodem" 28 - powiada filozof i, podążając śladami wędrówki ducha ludzkiego, wyznacza trzy części Europy. Pierwszą jest południowa Europa - zwrócona w stronę Morza Śródziemnego, w tym Italia i Grecja, gdzie „[...] przez długi czas była widownia dziejów powszechnych, i kiedy środek tudzież północ Europy były nieokrzesane, duch świata znalazł tutaj swą siedzibę"29. Druga z części to "serce Europy”, do którego Hegel zalicza Francję, Niemcy i Anglię. Za trzecią część Europy uważa on południowo-wschodnie państwa Europy - Polskę, Rosję i państwa słowiańskie, więc także i Ukrainę. „Późno dopiero wchodzą one do szeregu państw historycznych i tworzą oraz utrzymują stale związek z Azją" - podsumowuje Hegel ${ }^{30}$. Azja

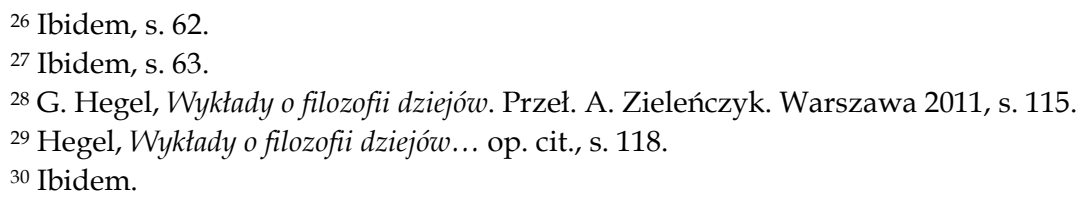


Wschodnia i kraje zaalpejskie to skrajne granice kultury europejskiej, ogniskującej się wokół Morza Śródziemnego. Ośrodek ten, zdaniem Hegla, stanowi „[...] początek i koniec dziejów powszechnych, ich wzejście i zajście" 31 .

Jak widzimy, nowoczesność oparta na oświeceniowej wizji rozumnego ducha oraz Europy jako centrum historii powszechnej przydziela Ukrainie rolę peryferyjną. Takie przeciwstawianie sobie centrum i peryferii cywilizacji europejskiej wywołuje istnienie stałego napięcia - od tamtego czasu aż po dziś dzień doścignięcie Europy oraz europeizacja są permanentnym motywem przewodnim wszystkich ukraińskich projektów nowoczesności.

Można również odnaleźć rozliczne współbrzmienia między peryferiami historii światowej - Azją, Afryką, Ameryką Łacińską - odpychanymi przez europocentryczną nowoczesność, oraz peryferiami samej europocentryczności - np. wschodnimi pograniczami Europy. Wśród cech wspólnych obserwujemy przede wszystkim opozycję zeuropeizowanej elity narodowej i marginalizację kultury ludowej (popularnej - w rozumieniu Dussela), jak również stałe pragnienie zbliżenia się do centrum, a więc realizacji ambicji europocentrycznych. Jednak możliwe jest także inne rozwiązanie. Rezygnacja ze stałej pogoni za europejską nowoczesnością jest zapewne - możliwa, pod warunkiem rezygnacji lub, mówiąc ściślej, skorygowania wektora swego ciążenia do centrum i włączenia się do procesów dialogu interkulturowego, który proponują peryferie. Znamienne przy tym, że teoria transnowoczesności i teoria dekolonizacji, opracowane przez filozofów południowoamerykańskich, włączają w orbitę swego dialogu również i Europę Wschodnią. Solidaryzując się z procesami samouświadomienia postępującymi na peryferyjnych pograniczach świata zachodniego (euroamerykańskiego), m.in. w krajach Ameryki Łacińskiej i Karaibów, Europa Wschodnia staje się podmiotem w dyskusji, która toczy się w świecie postkolonialnym i w której zlewają się ze sobą głosy Trzeciego i Drugiego Świata.

\section{(Z języka ukrainskiego przełożył Marcin Gaczkowski)}

${ }^{31}$ Ibidem, s. 102 